\section{Channels of small-arms proliferation: policy implications for Asia-Pacific}

\section{Stefan Markowski, Stephanie Koorey, Peter Hall, and Jurgen Brauer}

I

is believed that between 50,000 and 100,000 people are killed each year by direct mall arms and light weapons fire (SALW), and that at least twice as many die indirectly as victims of SALW-driven conflicts. ${ }^{1}$ In this article we are interested in small arms (rather than in light weapons), particularly when held and traded illicitly. Specifically, we first review a recently proposed multi-channel small arms supply-chain model. ${ }^{2}$ While we believe that the model has universal application, we restrict ourselves here to a brief description of some salient features of illicit smallarms stocks and flows in Asia-Pacific, and then spell out some policy implications for the region.

The model

Figure 1 captures the gist of a model that identifies the major holders of stocks and traces the (legal and illegal) imports and internal flows of new and used small arms. ${ }^{3}$ Briefly, on the left-hand side of the figure, legally-held stock in government and private hands is fed by legal imports and legal domestic manufacture. ${ }^{4}$ This stock can of course be internally traded, for example legal sales from government depots to private citizens, or among private citizens, but this is not further considered here. On the right-hand side of the figure, illicitly-held stock is fed by leakages from legallyheld stock, illicit domestic manufacture, and various forms of illicit imports. The latter may involve donated supplies by friendly powers or nongovernmental benefactors and are shown in Figure 1 as "illicit imports: foreign-power assistance" and "illicit imports: foreign nongovernment assistance," respectively. In Southeast Asia, for example, arms were transferred to Cambodian factions during the reign of the Khmer Rouge. ${ }^{5}$ Many of these weapons have been re-shipped across the region and beyond. In terms of nongovernment involvement in arms transfers, for example, both the United Wa State Army and the Patani United Liberation Army in Thailand have been accused of involvement in arms transfers to other armed movements. ${ }^{6}$ Presently, neither of these sources of weapons constitute major inflows into the Asia-Pacific region anymore. While some shipments from abroad may have been free of charge, the recipient may still have to collect them from a particular drop-off point that may be difficult and risky to arrange. As, by definition, these imports are clandestine, the last leg of the delivery process may also necessitate the recipient's direct involvement. This may stretch the recipient's resource base and impose significant transaction costs. The precariousness of external sources is noted by a member of the Moro
Illicit imports: nongovernmental assistance

Illicit imports: foreign-power assistance

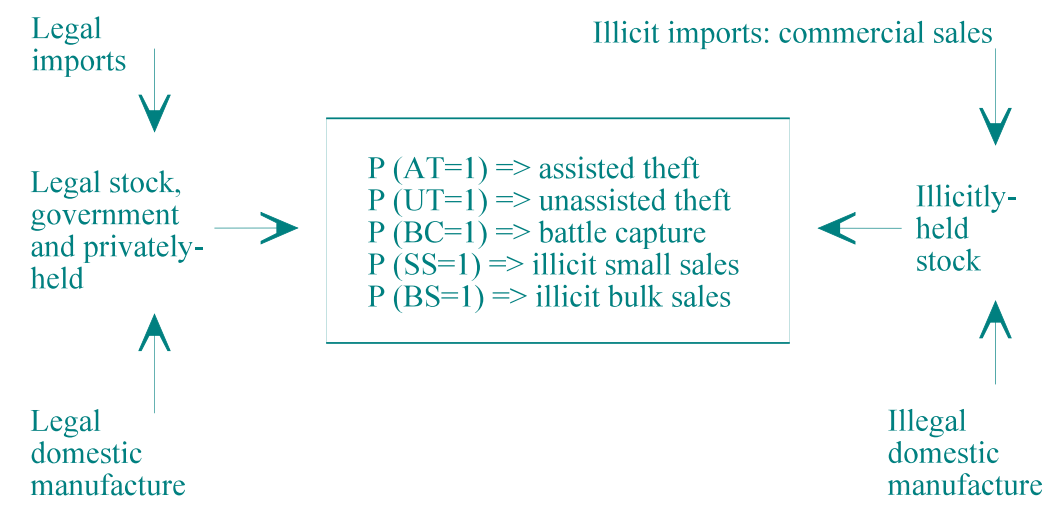

Figure 1: Small arms legal and illegal stocks and flows

Islamic Liberation Front of the Philippines, stating that external arms sources were both "expensive and risky," not to mention the process being "long."7

Commercial imports arranged through international (black market) arms dealers, shown in Figure 1 as "illicit imports: commercial sales," may also require a complementary in-kind effort from the recipient to obtain them, and must be paid for at prices set in the arms black market. In some cases, the commercial arrangements take the form of countertrade with firearms paid for by reverse shipments of narcotics or similar barter arrangements. For example, remnants of the Khmer Rouge were supplied with arms from Thailand and bartered for gem and logging concessions in the late 1990s, and the Mong Tai Army, headed by the "opium king" Khun Sa, was said to have bartered narcotics for SA-7 missiles from Cambodia. ${ }^{8}$

But the figure highlights, in particular, within-country transfers (leakages) of small arms from legal to illicit stocks (see the box inside the figure). We focus on five illustrative channels. For example, AT refers to assisted theft, such as when an armory guard is bribed to leave weaponry unguarded. Each channel is either open (e.g., $\mathrm{AT}=1)$ or closed $(\mathrm{AT}=0)$. Thus, $\mathrm{P}(\mathrm{AT}=1)$ denotes the probability that the assisted theft channel is active. UT is unassisted theft, a raid on an arsenal for example or theft from private homes or retail outlets. For example, in 2000, the Malaitan Eagle Force raided 
the state armories of the Solomon Islands. ${ }^{9}$ Weapons captured in armed encounters between rebel forces and military or police forces are designated as battle capture, BC. For example, in Burma (Myanmar), insurgents used an advance of the Burmese army as an opportunity to obtain new weaponry cost-effectively by ambushing the advancing army units. ${ }^{10}$ Illicit small sales, SS, reflect the case of government officers "losing" their service weapon or legal arms traders selling firearms illegally to insurgents or criminals. For example, a former combatant in the East Timorese independence movement, Falintil, described how occupying Indonesian forces would sell small amounts of arms and ammunition to members of Falintil. ${ }^{11}$ And illicit bulk sales, BS, refer to legal firearms holders engaging in bulk sales of weapons, such as when the Indonesian armed forces were shipping weapons "still in crates" to the separatist movement in the northwestern region of Aceh, orchestrated, according to one writer, by "corrupt generals" for whom it was just "a business deal." ${ }^{12} \mathrm{P}(\mathrm{UT}=1)$, $\mathrm{P}(\mathrm{BC}=1), \mathrm{P}(\mathrm{SS}=1)$, and $\mathrm{P}(\mathrm{BS}=1)$ denote the probabilities that the illicit channels, UT, $\mathrm{BC}, \mathrm{SS}$, and BS are active. All examples are illustrative and could be multiplied.

With the help of Figure 2, we discuss the concepts of complexity and dependability of supply-chain channels. For illustration, we pick the assisted theft channel and consider a number of paths along which firearms can move from legal to illicit stocks. Suppose that there are two independent initiators $\left(\mathrm{AT}_{11}\right.$ and $\left.\mathrm{AT}_{12}\right)$ who are willing and able to illegally divert firearms from a government depot. They may or may not know each other's identity, nor the identities of the other elements in the supply chain and of the ultimate recipient/s. $\mathrm{AT}_{11}$ is assumed to deal directly with five second-tier intermediaries, $\mathrm{AT}_{21}$ to $\mathrm{AT}_{25}$, while $\mathrm{AT}_{12}$ deals with only $\mathrm{AT}_{24}$ and $\mathrm{AT}_{25}$. $\mathrm{AT}_{21}$, in turn, can forward arms only to a third-tier intermediary, $\mathrm{AT}_{31}$, who supplies the illicit end-destination. The second-tier intermediaries $\mathrm{AT}_{22}$ to $\mathrm{AT}_{24}$, can each deal with either $\mathrm{AT}_{31}$ or $\mathrm{AT}_{32}$, who deliver firearms to the end-destination. In contrast, $\mathrm{AT}_{25}$, although only a second-tier intermediary, forwards directly to the final recipient.

Certainly, this is a complex if hypothetical network of transfer paths. These paths can be open or closed, they can be one-off or recurrent, they can be routine and frequently used or rarely used, they can be dormant for awhile and then be reactivated, and so on. On the part of the middlemen and final recipients this probably implies path-specific investment and maintenance costs, and perhaps switching costs as well if paths (and channels) are changed. The picture is further complicated when one considers that several originating and recipient stockpiles each may be linked concurrently, and that our comments hold for the other channels (UT, BC, SS, and BS) equally well.

The dependability of the system as a whole increases if the number of channels, $z$, increases and alternative $a$ channels can be used to meet the end-user requirement. Similarly, the availability of alternative paths within a channel increases the channel's dependability. For example, in Figure 2, each path from the legally to illegally-held stocks consists of a series of arms transfers among different intermediaries. If one of these intermediaries is removed from a sequence, the path under consideration is

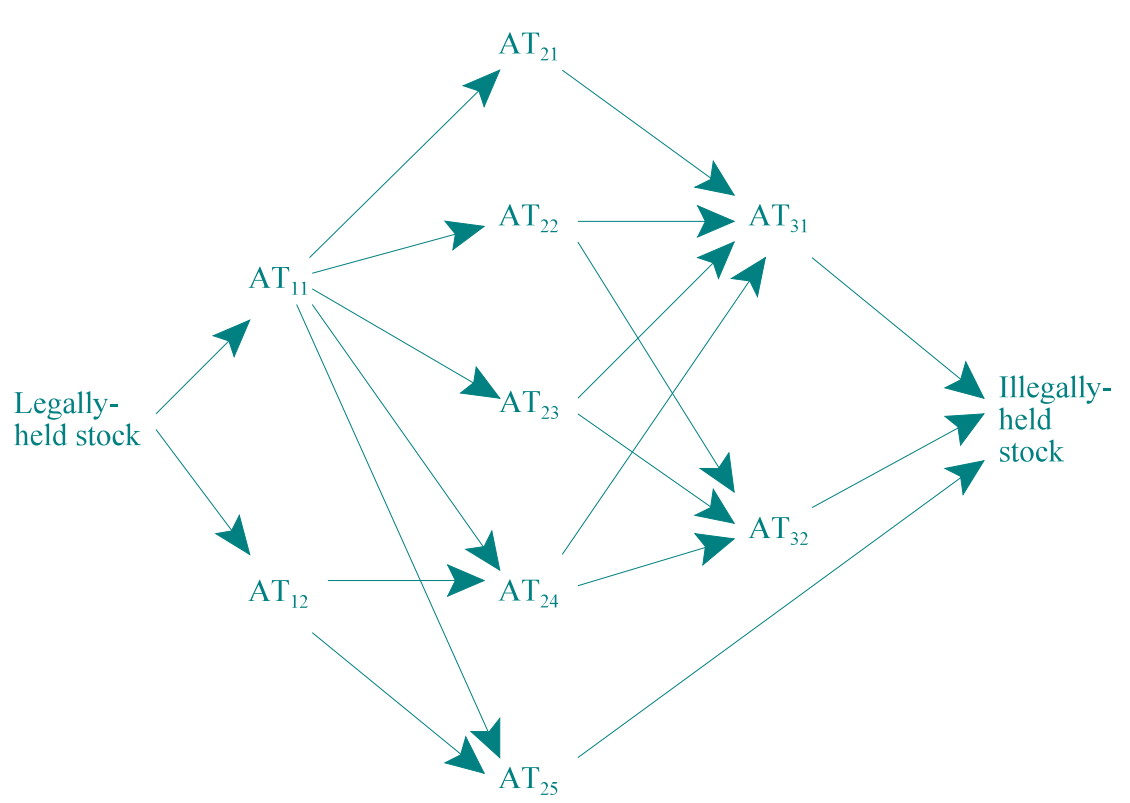

Figure 2: Supply-channel complexity

disabled. Thus, the path $\mathrm{AT}_{11} \Rightarrow \mathrm{AT}_{21} \Rightarrow \mathrm{AT}_{31}$ is active as long as all three intermediaries are active. Eleven parallel paths comprise the assisted theft channel, AT, in Figure 2. Listed sequentially, they are:

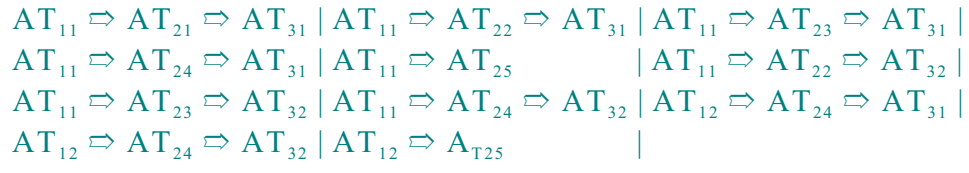

If only a single firearm is to be leaked from the legally to illegally-held stocks, it would be sufficient for only one of the eleven paths to be open and successful in getting the weapon to its end-destination. The parallel arrangement of delivery paths in the AT-channel provides redundancy so that if any one path is disabled each one of the remaining paths is a perfect substitute for it. When a larger quantity of firearms is required at the illicit destination, two or more paths will have to be used to meet the requirement. In the latter case, the transfer capacity of each delivery path would have to be considered. The amount of intra-channel redundancy is a function of both the quantity of weapons needed and the transfer capacity of each channel. 
The parallel arrangement of paths within each channel and channels within the supply chain is more robust than the series arrangement (a linear configuration of intermediaries between legally and illegally-held stocks). This is because disruption of particular flows or disablement of a supply channel may have no impact on the overall quantity supplied as other paths and channels are available. When the supply chain is arranged as a parallel (multi-channel) delivery system, it is more dependable as it is relatively easier to tie the source of weapons to its end destination. It is, thus, more difficult for government agencies to cut across the parallel structure to disable the supply chain. For example, to effectively disable the supply channel shown in Figure 2, government agencies would have to "take out" the first tier of intermediaries $\left(\mathrm{AT}_{11}\right.$ and $\left.\mathrm{AT}_{12}\right)$, or all of the second tier $\left(\mathrm{AT}_{21}\right.$ to $\left.\mathrm{AT}_{25}\right)$, or the third $\left(\mathrm{AT}_{31}, \mathrm{AT}_{32}\right.$, and $\mathrm{AT}_{25}$ ), or some other combinations of intermediaries at different tiers. Naturally, it is as much in the interest of illicit small-arms recipients to minimize the probability of system disruption or disablement by building redundancy into the supply chain as it is in the presumed interest of government to maximize that probability.

Even from this rudimentary discussion, it must be clear that successfully and continuously disrupting illicit small-arms flows is a daunting undertaking. We return to this in our outline of policy implications.

Features of small-arms stocks and flows in Asia-Pacific

By all appearances, trade in illegal small arms flourishes in South and Southeast Asia and the West Pacific. ${ }^{13}$ Despite the absence of active interstate wars in the region, several ongoing intrastate conflicts generate demand for small arms. Most markedly, Burma (Myanmar) and the Philippines remain host to a number of protracted insurgencies. Ethnically-based armies continue to pepper the Thai-Burmese border The Philippines is host to the region's most serious communist insurgency, the New People's Army, as well as a number of factionalized Islamist groups in the southern islands of the country. A long-running secessionist movement in Aceh in the northwest of Indonesia reached a negotiated end only in 2005, and a resurgent Islamist insurgency has simmered in Thailand's south since 2004. In recent decades, there have been armed conflicts in the western Pacific in Bougainville, eastern Papua New Guinea, Fiji, and in the Solomon Islands. The southern highlands region of Papua New Guinea is notorious for local outbreaks of violence. Insurgencies and rebel movements numbering tens of thousands of armed participants are active in Nepal and Northeast India as well, and a long-running civil war plagues Sri Lanka. ${ }^{14}$ To some measure, nonstate actors in these conflicts have used small arms that are either leaked from official stockpiles or fabricated by the combatants themselves.

Some state actors appear to seek to bolster the military capacity of friendly movements elsewhere if they see it as politically expedient to do so. For example, for several decades Thailand helped to construct a bulwark of armed nonstate actors along its border with Burma, keeping both Burmese and communists at bay. ${ }^{15}$ Various groups hold arms illicitly and sharp distinctions among them cannot easily be drawn. For example, small arms tend to be acquired and used by insurgents and/or criminal elements. These groups often functionally overlap as many insurgent groups crosssubsidize their primary activities (the armed struggle) by engaging in secondary criminal activities, such as kidnappings and extortion, protection rackets, narcotics trade, and plain robbery. For example, the United Wa State Army (UWSA) in Burma was a former communist insurgent group that, since the ceasefire with Burma's military regime, has grown to become a major illicit exporter of narcotics (heroin and methamphetamines) and trafficker of small arms into Laos, Cambodia, and India's northeast regions. ${ }^{16}$ This is the case of the poacher turned gamekeeper as, since the ceasefire, the UWSA also has become an important and highly influential ally of the Burmese military government. This is not to say that all nonstate entities are inherently criminally inclined. At least at the outset, some insurgent groups see themselves as legitimate entities (that is, governments-in-waiting), provide social services, and collect taxes in regions under their direct control. Weapons are also redirected to paramilitary entities that act as adjuncts to national security forces. The Indonesian-backed militias in East Timor at the time of the latter's vote for independence in 1999 are probably the most notorious example of paramilitarization in the region. ${ }^{17}$

It appears that over the past few years, ideologically motivated cross-border supplies have become less significant in Southeast Asia. China was a major supplier of small arms to protégé groups in the region - for example, the Khmer Rouge in Cambodia were receiving supplies well into the 1990s and Chinese arms have reached nonstate entities in northeastern Burma and India - but there is no evidence of current large-scale transfers to armed insurgent groups for political, nor even financial, gain. There are also indications that cross-border traffic in small arms has been in decline recently. ${ }^{18}$

Small arms in the hands of nonstate actors range from pre-WWII era rifles to recently-issued weapons. Asia-Pacific, as defined in this article, is not a market characterized by large injections of new weapons from outside the region, but is typified by the recycling of older weapons. This is especially the case in Southeast Asia, where the wars in Cambodia and Vietnam - linchpin arms supply states - left a legacy of huge quantities of small arms still circulating in the region. For example, two million Soviet arms and over 270 million rounds of ammunition were supplied between 1964 and 1971 to North Vietnam. ${ }^{19}$ Departing U.S. forces left behind in Vietnam over 150,000 tons of ammunition and over two million small arms including handguns, assorted rifles including M16A1s, M60s, and grenade launchers. American small arms transfers to Laos and Cambodia from 1950 to 1975 totaled over 500,000 items. Vietnam War-era weapons have subsequently been re-exported to as far as Cuba and Latin America and, closer to the source, to the New People's Army in the Philippines. Ex-Vietnam small arms have also been included in drug shipments to Hong Kong and sent back to collectors and dealers in the United States. ${ }^{20}$ Similar 
examples can be provided for Cambodia.

While not listed in any order of significance or magnitude, the main transfer features of the illicit South and Southeast Asian small arms market are smuggling across borders, leakage from state security stocks, and the capture and fabrication of weapons within conflict zones. Such smuggling and leakage also takes place in the West Pacific but battle-captures there are minimal, and the fabrication of weapons, usually craft production, is not as sophisticated as elsewhere in the region.

Weapons old and new are also taken from state stockpiles (leakage), seemingly the principal source of small arms acquired by insurgents and criminal elements. Governments originally acquired these arms legitimately from domestic or foreign sources, i.e., from either private or government manufacturers and/or foreign governments. The leakage can be due to poor stockpile management (linked to weak state management and administration, corruption, or inadequate stockpile security) or due to deliberate siphoning-off of weapons for personal or political gain. Weapons are also captured from government stocks through raids that can be violent or cleverly exploitative, with targets including armories, convoys, checkpoints, and outposts as well as individuals employed in the security sector. Other forms of leakage range from the sale of bullets and grenades by soldiers on the front line to large shipments arranged by officers or officials as business deals. ${ }^{21}$

The relatively simple technology of the weaponry and the protracted nature of many of the conflicts have encouraged the craft production of small arms in the region. ${ }^{22}$ Craft-produced weapons in the Pacific are mostly simple arms fabricated to look like military firearms but with limited attention paid to quality and utility for warfighting conditions. While craft producers are often highly skilled, they may only have access to poor-quality materials. Nonetheless, craft production can be quite significant in terms of numbers of weapons. For example, craft-produced small arms comprised almost three-quarters of those handed over in the Solomon Islands in 2000$01 .^{23}$ Gunsmithing techniques are more advanced in mainland South and Southeast Asia with a number of craft producers, including many arms holders themselves, demonstrating a capacity for firearm, mortar, rocket-propelled grenade, and ammunition manufacture and refabrication. ${ }^{24}$ For example, gunsmiths in the Philippines are known for their craftsmanship and, thus, able to produce and/or modify more sophisticated weapons. Craft-industry weapons may compete on price and availability with other sources of illicit supply.

\section{Policy implications}

Initiatives to restrict the proliferation of small arms have been prominent in recent years. ${ }^{25}$ A catalyst was the U.N. 2001 Programme of Action to Prevent, Combat and Eradicate the Illicit Trade in SALW. The U.N. Firearms Protocol signed in 2001, the first binding global agreement on small arms, came into force in 2005. But to develop effective policy to contain SALW, it is necessary to have a good understanding of how illicit small arms are distributed and illicit stocks formed. As the first section of this article has suggested, to date, not only are the mechanics of SALW supply chains still poorly understood, but the structural complexity of illicit supply chains is likely to be considerable. Moreover, as we argue below, small arms proliferation is often a symptom of other, deeper problems that need to be confronted if small arms-related trafficking is to be contained.

As mentioned, the single-channel arrangement (the pure series supply chain) offers the greatest potential for a government seeking to disable the flow of small arms to illicit holders. In this case, it is sufficient to remove any one of the elements comprising the supply chain to break the tie between the input and the output and, thus, disable the flow of illicit small arms. To disable a multi-channel supply chain, the government would have to disable (cut through) every channel and, as channels are likely to comprise many parallel delivery paths, at least one element of every path. To reduce the cost of intervention, the government should identify a minimal set of all elements it wished to disable so that the entire multi-channel supply chain could be disabled cost effectively. In reality, when the number of channels, $z$, is large, and each channel comprises many delivery paths, it is rather unlikely that governments of countries threatened with insurgency and/or faced with a large-scale criminal sector have the necessary resources to disable the flow of firearms to illicit stocks. ${ }^{26}$ To be cost effective, the government may have to concentrate on the most vulnerable channels and target weak links along every delivery path. For example, it may reduce the flow of arms by aiming to disable the channels with the greatest throughput capacity. Or it may target particular types (tiers) of intermediaries. The cost of removing elements of supply channels may be measured in money terms or in terms of the physical effort required to disable a particular link (e.g., the scale of military operations needed or the number of government infiltrators/spies planted in insurgent and criminal organizations). However, to identify and remove all weak links, the government would need superior intelligence about the structure of the supply chain to decide on the most resource-effective course of action. In practice, the presence of informational asymmetries and the cost of securing the relevant intelligence would make the identification of weak elements of each channel most unlikely. For example, the assisted theft channel may comprise many people who are prepared to steal arms from the government stock. They may do so for personal, political, or ideological reasons. They may also engage in theft to assist illicit arms holders as a protection payment (economically, an "insurance premium") to ensure that they or their families are not targeted in armed attacks and kidnappings. As threats posed to the government by illicit arms holders are essentially asymmetric, they are often intended to coerce those involved in the machinery of government to induce their tacit support and collaboration. There also may be numerous people who steal from government stocks for financial gain, particularly in instances where the government sector is inherently corrupt or where security sector personnel are inadequately paid.

As the number of elements in the supply chain and, in particular, the number of 
channels, increase, while only some channels, say $y$ out of $z$, are needed to meet the demand for illicit arms, the sheer complexity of the supply chain makes it very costly to identify even a single set of vulnerable links (a "cut set" of links) that could be effectively targeted and disabled. Such complexity in the multi-channel supply chain and the associated information asymmetries are the essence of the challenge faced by those aiming to stop the proliferation of small arms.

The challenge becomes even greater when disabling a supply chain requires collaboration between two or more governments. For example, consider the case of illicit commercial imports of weapons. A supply chain may originate in a country where large quantities of small arms remain from a previous conflict (e.g., Cambodia). These stocks are often dispersed among the local population, which sells them to local arms dealers, who in turn may resell to international dealers. The latter arrange transport to illicit buyers in the destination country. In this case, the government in the destination country can do little to disable the upstream segment of the supply channel unless the government of the source country is prepared to cooperate. In the exporting country, the government has more options to disable the in-country segment of the supply channel. For example, as the population itself constitutes a set of supply-chain intermediaries, the government can arrange a buy-back program to crowd out local arms dealers. Firearm ownership could be made illegal and all existing owners ordered to surrender their weapons within a designated time period and in exchange for a set fee (or by arranging some form of gun-amnesty). But to be successful, the government would have to buy a sufficient quantity of the weapons and this would drive the black market price up. At times, this has produced perverse results as higher prices for old weapons allows arms holders to sell them to the buy-back agency and use the money to purchase newer weapons smuggled in to meet demand. Essentially, buy-back programs are government demand and function as a siphon that draws in new supplies. Alternatively, governments may arrange crackdowns on local arms dealers to drive them out of business (to remove another set of intermediaries to disable all those channels that depend on their services for effective operation). There is less scope for either source or destination country governments to drive international arms dealers out of business as they are likely to be located outside the jurisdiction of both governments.

The analysis presented here highlights the sheer complexity of the multi-channel supply chain formation. Some of that complexity is likely to be a matter of deliberate design on the demand side of arms trafficking when illicit arms-holders diversify sources of supply to enhance the robustness of the supply chain. But some of it may be intrinsic to the socioeconomic makeup of a country under consideration. That is, the combination of corruption, poverty, ethnic and religious tensions and political instability, and previous or ongoing conflict provide many opportunities for arms delivery initiatives to originate on the supply side of the arms flow. The combination of these demand and supply factors makes it very difficult for any government to identify minimal sets of vulnerable links that must be cut to disable the associated supply channels. In this respect, illicit arms supply chains are even more difficult to deal with than supply chains for illegal drugs. While the supply chain for illegal drugs is driven almost entirely by (black) market forces alone, in the case of illicit arms flows there are additional political, ideological, financial, religious, and ethnic factors that influence the direction, complexity, and intensity of arms flows.

To significantly restrict the flow of weapons by illicit arms holders requires, on the logic of this article, superior intelligence, massive resources, and incorruptible enforcement agencies, few of which are ordinarily available to governments, especially those of developing countries. Moreover, as the opportunity cost of these resources in developing countries is likely to be perceived as high by policy makers, we would not expect much effort to be devoted to small arms reduction. The odds are in favor of illicit arms suppliers and recipients who, given the scope for channel redundancy, can easily tie the sources of supplies to their illicit destination. In contrast, to be effective, governments would have to disable a large number of active and dormant supply channels. Governments thus often turn a blind eye to illicit arms flows. It is only when violence associated with the proliferation of small arms poses a credible threat to economic growth or government survival that the marginal benefit of small arms reduction increases and induces government to devote more resources to the disablement of illicit supply channels.

Most importantly, however, the proliferation of illicit small arms is a symptom of a deeper socioeconomic malaise rather than its cause. For example, when corrupt or unprofessional elements in the security sector sell their weapons to insurgents or criminals, the problems to address are the lack of professionalism and all-pervasive corruption in the public sector. Unless corruption is stamped out, those with access to government stocks will find a way of facilitating firearm transfers to illicit holders. In the short run, much-publicized initiatives to disable supply channels, such as arms buy-backs, may have some useful demonstration effects but, given the complexity of supply chains, they are unlikely to have much impact on the illicit stocks and flows. But as the experience of East Asia shows, if long-run economic growth accelerates and its benefits are widely shared, the incentives to supply and demand small arms change at both ends of the supply chain. While there are pockets of active insurgency, there appears to be less small arms-fueled violence in South and Southeast Asia than a decade or two ago. By contrast, in the Pacific, where the slowly developing island economies are poorly integrated into the international division of labor, firearmsrelated violence has increased. ${ }^{27}$ In our view, the key challenge for governments that 
are serious about small arms-fueled violence is to address the opportunity cost of holding and using illicit arms, and this is a challenge for economic policymakers rather than security agencies. In this regard, more studies examining successful cases of limited penetration of small arms in host populations would be most welcome.

\section{Notes}

Stefan Markowski and Peter Hall teach at the University of New South Wales at the Australian Defence Academy in Canberra, Australia, Stepahnie Koorey lectures at the Australian National University, Canberra, Australia, and Jurgen Brauer is at the James M. Hull College of Business, Augusta State University, Augusta, USA. The corresponding author, Dr. Markowski, may be reached ats.markowski@adfa.edu.au.

1. These "real weapons of mass destruction" (SAS, 2001, p. 1) include revolvers and self-loading pistols, rifles and carbines, assault rifles, submachine guns, and lightmachine guns, and light weapons such as heavy machine guns, handheld under-barrel and mounted-grenade launchers, portable antitank and antiaircraft guns, recoilless rifles, portable launchers of antitank and antiaircraft missiles, and mortars of less than $100 \mathrm{~mm}$ caliber (U.N. Panel of Governmental Experts on Small Arms, 1997, in SAS, 2006, p. 9). The U.N.'s definition is policy-oriented, developed to build a practical framework to address the challenges posed by widespread use of SALW in numerous conflicts in developing countries.

2. See Markowski, et al. (forthcoming).

3. We focus on stocks of firearms at a point in time (or averages of stocks held over a period of time). Clearly, there are deletions from as well as additions to stocks, e.g., some firearms can be exported or destroyed. Legally-held small arms awaiting their shipment overseas or destruction are included in legally-held stock in Figure 1.

4. This stock includes inventories of finished and semi-finished firearms held by legal arms manufacturers.

5. Capie, 2002 (pp. 28, 97-98, 100-101).

6. FEER (2000); Capie (2002, p. 41)

7. Davis (2003b, p. 33).

8. Phongpaichit, et al. (1998, pp. 145-148); Davis (2003c, p. 17).

9. Alpers and Twyford (2003, p. 39).
10. See Smith (1999, p. 307). Clearly, arms can also be captured from insurgents, and often are, by government forces. This results in a negative value for $\mathrm{BC}$, that is, a net removal of weapons from illicit stocks, and is not explicitly shown in the figure.

11. Pinto and Jardine (1997, p. 102). These retail activities are often opportunistic, ad hoc, and small scale. In their totality, though, they may be quite significant.

12. Kingsbury (2003, p. 209). Alternatively, they may sell intelligence or leave the gates open to insurgents or criminals.

13. See, for example, Alpers (2005); Alpers and Twyford (2003); Buchanan and Atwood (2002); Capie (2002, 2003); Davis (2003a, b); Phongpaichit, et al. (1998).

14. Interestingly, within India the northeast and the continuing conflict in Sri Lanka, involving Tamil residents in the southern Indian province of Tamil Nadu, receive more attention in daily discussions than do the nuclear-arms aspirations of China, India, and Pakistan.

15. Phongpaichit, et al. (1998, p. 129); Smith (1999, p. 277).

16. Davis (2003a)

17. Greenless and Garran (2002).

18. Davis (2003a); Buchanan and Atwood (2002); Phongpaichit, et al. (1998).

19. Capie (2002).

20. Examples drawn from Ezell (1988) and Capie (2002).

21. Buchanan and Atwood (2002, p. 21).

22. Small arms production involves mature technology. When commercial considerations dominate, more sophisticated technologies would be accessible for illicit gunsmiths once prices increase enough to allow them to buy high-quality materials and devote more effort to high-quality machining of components. Ultimately, many top-quality civilian small arms are made by hand by jobbing gunsmiths.

23. Capie (2002, p. 73); TT (2005); Alpers (2005, p. 45); Alpers and Twyford (2003, p. 25) 


\section{Buchanan and Atwood (2002).}

25. Stohl, Schroeder, and Smith (2007).

26. For discussion see Markowski, et al. (forthcoming).

27. Alpers and Twyford (2003); Capie (2003).

\section{References}

Alpers, P. 2005. "Gun-Running in Papua New Guinea: From Arrows to Assault Weapons in the Southern Highlands." Geneva: Small Arms Survey.

Alpers, P. and C. Twyford. 2003. "Small Arms in the Pacific." Occasional Paper No. 8. Geneva: Small Arms Survey.

Buchanan, C. and D. Atwood. 2002. "Curbing the Demand for Small Arms - Focus on Southeast Asia." A summary report from the workshop held on 26-31 May 2002, Phnom Penh, Cambodia. Geneva: The Center for Humanitarian Dialogue and The Quaker United Nations Office.

Capie, D. 2002. Small Arms Production and Transfers in Southeast Asia. Canberra Papers on Strategy and Defence No. 146. Canberra: Strategic and Defence Studies Centre, Australian National University.

Capie, D. 2003. Under the Gun: the Small Arms Challenge in the Pacific. Wellington, New Zealand: Victoria University Press in association with the Peace and Disarmament Education Trust, Department of Internal Affairs, Wellington.

Davis, A. 2003a. "The Wa Challenge Regional Stability in Southeast Asia." Jane's Intelligence Review (January).

Davis, A. 2003b. 'Philippine Security Threatened by Small Arms Proliferation." Jane's Intelligence Review (August).

Davis, A. 2003c. "Southeast Asia Fears New Terrorist Attacks." Jane's Intelligence Review (November).

Ezell, E.C. 1988. Small Arms Today. 2nd ed. Harrisburg, PA: Stackpole.

[FEER] 2000. “Burma's Wa Run Guns." Far Eastern Economic Review Vol. 163, No. 2.

Greenlees, D. and R. Garran. 2002. Deliverance: The Inside Story of East Timor's Fight for Freedom. Sydney: Allen and Unwin.

Kingsbury, D. 2003. Power, Politics and the Indonesian Military. London: Routledge Curzon.

Markowski, S., S. Koorey, P. Hall, and J. Brauer. Forthcoming. "Multichannel Supply-Chains for Illicit Small Arms." Defence and Peace Economics.

Phongpaichit, P., S. Piriyarangsan, and N. Treerat. 1998. Guns, Girls, Gambling, Ganja: Thailand's Illegal Economy and Public Policy. Chiang Mai: Silkworm Books.
Pinto, C. and M. Jardine. 1997. East Timor's Unfinished Struggle: Inside the Timorese Resistance. Boston: South End Press.

SAS (2001) Small Arms Survey 2001: Profiling the Problem, Oxford: Oxford University Press.

SAS (2006) Small Arms Survey 2006: Unfinished Business, Oxford: Oxford University Press.

Smith, M. 1999. Burma: Insurgency and the Politics of Ethnicity. London: Zed Books.

Stohl, Rachel, Matt Schroeder, and Dan Smith. 2007. The Small Arms Trade: A Beginner's Guide. Oxford, UK: Oneworld. Publications.

[TT] 2005. "Filipino Gunsmiths are Making a Killing." Taipei Times (online). 7 May. 